Research Article

Magdalena Ujma*

\title{
Jan Sobieski's latifundium and the soldiers (1652-1696)
}

https://10.1515/openms-2020-0105

Received Oct 26, 2020; accepted Nov 07, 2020

\begin{abstract}
An analysis of the relationship between Jan III Sobieski and the people he distinguished shows that there were many mutual benefits. Social promotion was more difficult if the candidate for the office did not come from a senatorial family34. It can be assumed that, especially in the case of Atanazy Walenty Miączyński, the economic activity in the Sobieski family was conducive to career development. However, the function of the plenipotentiary was not a necessary condition for this. Not all the people distinguished by Jan III Sobieski achieved the same. More important offices were entrusted primarily to Marek Matczyński. Stanisław Zygmunt Druszkiewicz's career was definitely less brilliant. Druszkiewicz joined the group of senators thanks to Jan III, and Matczyński and Szczuka received ministerial offices only during the reign of Sobieski. Jan III certainly counted on the ability to manage a team of people acquired by his comrades-in-arms in the course of his military service. However, their other advantage was also important - good orientation in political matters and exerting an appropriate influence on the nobility.

The economic basis of the magnate's power is an issue that requires more extensive research. This issue was primarily of interest to historians dealing with latifundia in the 18th century. This was mainly due to the source material. Latifundial documentation was kept much more regularly in the 18th century than before and is well-organized. The economic activity of the magnate was related not only to the internal organization of landed estates. It cannot be separated from the military, because the goal of the magnate's life was politics and, very often, also war. Despite its autonomy, the latifundium wasn't isolated. Despite the existence of the decentralization process of the state, the magnate families remained in contact with the weakening center of the state and influenced changes in its social structure. The actual strength of the magnate family was determined not only by the area of land goods, but above all by their profitability, which depended on several factors: geographic location and natural conditions, the current situation on the economic market, and the management method adopted by the magnate. In the 17th century, crisis phenomena, visible in demography, agricultural and crafts production, money and trade, intensified. In these realities, attempts by Jan III Sobieski to reconstruct the lands destroyed by the war and to introduce military rigor in the management center did not bring the expected results. Sobieski, however, introduced "new people" to the group of senators, who implemented his policy at the sejmiks and the Parliament, participated in military expeditions and managed his property.
\end{abstract}

\section{Keywords:}

Magnate estates constituted a complex of landed estates located in various parts of the First Polish Republic. These vast territories provided a source of income for the upper class of the nobility, which dominated the middle nobility in the second half of the 17th century and pursued their own political goals. Latifundia were characterized by high self-sufficiency. They were created thanks to the seizure of land of small owners for debts, thanks to redemptions, and thanks to the grants of the rulers. The land of magnates gathered a large clientele of magnates who were looking for a source of income and a chance for social promotion here. For

*Corresponding author: Magdalena Ujma

๖ Open Access. () 2020 Magdalena Ujma, published by De Gruyter. (G) Br This work is licensed under the Creative Commons Attribution 4.0 Public License. 
representatives of the middle nobility, military service still offered such a chance. The system of informal relationships in the sphere of economics and politics is called clientelism. It consists in the fact that an influential and wealthy decision-maker takes care of a person or a group of people, for example in exchange for political support or other favors. As Urszula Augustyniak emphasized, the phenomenon of clientelism gained importance when the royal court lost the ability to engage the nobility in administration or military service, and then the impoverished nobility was forced to depend on the magnates ${ }^{1}$. In the case of Jan Sobieski, a magnate and then king, patronage became attractive to the nobility because, as a monarch, Jan III had the opportunity to grant high state offices to persons he chose. These were people who remained in his circle even when he was a young magnate.

In the times of Jan Sobieski, the works of Xenophon, who was a soldier and also a diligent host, were still popular In the 17th century, the Roman maxim comparing a landed estate to an army, and its owner to an ordering commander as on a battlefield, was still popular. Jan Sobieski was born the son of a magnate, so his destiny was politics, and his military talent allowed him to win the royal crown. He was also a frugal man, caring for his earthly goods. Thanks to Sobieski's respect for military service and the economy, people with modest social origins, thanks to military service and work in the Sobieski family's latifundium, could achieve high state offices and, over time, join the ranks of the magnates. The growing importance of the magnates was accompanied by the decentralization of the state, including the weakening of the old Polish parliament. The property power of magnates and the offices and dignities they held - almost importantly the hetman's office - gave them power and prestige only slightly inferior to the influence of the king. However, this did not mean that power was easy to maintain. At a time when the state was threatened by numerous wars and internal conflicts, it was necessary to remove the devastation of war in land estates, fight the abuses of their administrators, and rebuild the economy in the countryside and in cities. The results of research on the organization and functioning of magnate latifundies are studies devoted to the property of individual people, families or groups of magnate families ${ }^{2}$. Thanks to their autonomy, latifundies functioned almost like a state within a state. They had their own hierarchy of offices as well as an army. This specific separation emphasized the decentralization of the territory of the state, but as a result of the election in 1674, a magnate became the king. In this way, the person of the monarch combined the weakening center of state power with magnate property. However, the boundary between state and private property was still blurred, and the interests of one's own family were often more important than those of the state. Scientific literature devoted to military science in the second half of the 17th century is already plentiful'. Its review has been presented, among others, by Zbigniew Hundert ${ }^{4}$. The importance of linking tax issues with military issues was noticed by Polish historians who, as part of the grant received, worked on the source edition "Treasury files as a source to the history of the Old Polish military during the reign of the Vasa (1587-1668)"'. English-language literature cannot be omitted either. Valuable is the collection of studies published by Gary Sheffield on military affairs from the 17th century to the present day ${ }^{5}$. William D. Godsey devoted his monograph to the extremely important issue of the relationship between the economy and the military, as are Aaron Graham and Patrick Walsh and Matthew Smith Anderson ${ }^{6}$. These are just some of the many examples that prove historians' interest in the history of European military in the 17th century.

\section{Brothers in arms in the central government}

Jan Sobieski took possession of the family latifundium in 1661, after the death of his mother, Teofila née Daniłłowicz. However, almost a decade earlier-as a result of the premature death of his older brother Marek - he took over his land estates, including those located in the Trans-Ukraine region. The administration of the seventeenth century latifundium was not as extensive as it was in the eighteenth and nineteenth centuries. The latifundial administration consisted of a lower management derived mainly from peasants, as well as a higher board recruited mainly from the landless nobility ${ }^{5}$. Jews were willingly employed in Jan Sobieski's latifund - mostly as tenants of taverns and accountants. The local management was located in individual granges, and the central management was at the top of the hierarchy. The central management was in the hands of the owner of the latifundium, who used the help of plenipotentiaries of his choice. Economic 
sources compiled in Jan Sobieski's latifundium, as well as in his correspondence, mention the names of senators coming from the middle nobility. They were all connected with him from their youth and owed him for their social advancement. Sobieski was able to learn about their advantages on the battlefield because they were his brothers in arms. This group included mainly Marek Matczyński, Stanisław Antoni Szczuka, Atanazy Walenty Miączyński and Stanisław Zygmunt Druszkiewicz. Szczuka and Miączyński, after Sobieski took the throne, received high state offices from him. More detailed information about their economic activities can be easily found in inventories, income and expense ledgers, as well as in other historical sources kept at the National Historical Archives of Belarus in Minsk ${ }^{6}$. The scope of the plenipotentiary's duties is helped by the correspondence written by Matczyński and Szczuka7. The work they did was very important because Sobieski was not always able to personally supervise the work of his staff. This was due to the expanding area of the latifundium, as well as frequent absences caused by travels and military expeditions.

The people whom Sobieski trusted had one common advantage - it was a joint military service, although their military talent is not judged equally. Atanazy Walenty Miączyński and Stanisław Zygmunt Druszkiewicz were experienced soldiers. Miączyński is considered to be one of the most outstanding officers of that time $^{8}$. Stanisław Antoni Szczuka and Marek Matczyński also participated in Sobieski’s military expeditions, although Matczyński's military spirits aroused controversy and he is not considered a soldier in the strict sense of the word 9 . These people were burdened with many duties, including controlling the organization of work in the latifundium and supervising financial matters.

The powers of the plenipotentiaries were not always strictly defined. On the other hand, the preserved historical sources allow to define their type and scope. The greatest activity in the management of Jan Sobieski's latifundium was Atanazy Walenty Miączyński, who came from the middle-class nobility settled in Volhynia ${ }^{10}$. He distinguished himself with particular energy in managing financial and organizational matters. For example, in 1671, as a royal colonel and courtier, he inspected the work of Michiel Bieniuszewicz, a leaseholder of the Zboiska farm in the Żółkiew estate, and then submitted a report on it ${ }^{11}$. Thanks to his zeal, he gradually reached the next levels of promotion. In 1682 he was the starost of Łuck, and from 1684 he was a crown hunter. In 1684, he prepared a list of arrears of money unpaid to the treasury by tenants in the Pielaszkowice ${ }^{12}$. Sobieski trusted him very much. Miączyński was also involved in organizing the purchase of earthly possessions from the hands of co-owners and securing funds allocated for this purpose ${ }^{13}$. In 1688, Miączyński became the court treasurer, but he continued to supervise the Sobieski family estates. The pleadings of his subjects addressed to Jan Sobieski were considered by this plenipotentiary. He was also involved in selecting candidates for tenants. The analysis of the duties incumbent on Miączyński shows that his main task was to act as the commissioner responsible for organizing and controlling the management and finances of the latifundium. The measure of trust that Jan III Sobieski placed in him was such that he performed his duties until the death of the monarch. The king's trust in Miączyński was not even undermined by the ruthlessness that his plenipotentiary showed to his subjects. In 1710, during the Northern War, when the issue of amnesty for the supporters of the King of Sweden was being discussed, Miączyński, who supported August II Wettin, lamented the loss of his 140 villages, burned down by the Swedish army $^{14}$.

Marek Matczyński started his career as a clerk during the reign of Jan Kazimierz Waza ${ }^{15}$. He started his work at the Jan Sobieski latyfundia very early on, even before his patron became the king. In the 1660s, he became a land clerk - in 1661 he received the office of Podolia, as well as the starost of Grabowiec ${ }^{16}$. During the reign of Jan III Sobieski, Matczyński achieved further promotions, but he did not cease his duties as plenipotentiary. In 1676 he became Crown equestrian ${ }^{17}$, and in 1689 the Crown Treasurer ${ }^{18}$. He resigned from the latter office in 1992 and was then appointed the Ruthenian voivode. Matczyński's duties included, among other things, overseeing the spending of money for various needs, including small ones ${ }^{19}$. He also controlled the correct payment of the salaries of the craftsmen working at the castle in Żółkiew ${ }^{20}$. He also took care of the provision of the Dominican nunnery in Kamieniec Podolski ${ }^{21}$. He was an intermediary between the king and the Lviv townspeople ${ }^{22}$. Therefore, he dealt with, among other things, ensuring the safety of the king during his stay in $\mathrm{Lviv}^{23}$. He was responsible for controlling finances in various parts of the latifundium. All in all, his tasks - as in the case of Miączyński - can be called financial and organizational. 
At the beginning of the reign of Jan III, Stanisław Antoni Szczuka was only the royal secretary, but in 1684 he was appointed regent of the major crown chancellery. Four years later he was already a crown secular referendary ${ }^{24}$. He dealt, inter alia, with granting loans to impoverished rural subjects. He was responsible for the approval of accounts prepared by local administrators ${ }^{25}$. Szczuka had a great influence on Jan III and was one of the king's most trusted people ${ }^{26}$. Jan III entrusted him with the role of the leader of the court party. Szczuka maintained his economic and political activity after the death of Jan III Sobieski. He enjoyed the grace of his successor, Augustus II Wettin, and in 1698 he became the lifetime administrator of all the goods that Prince Jakub Ludwik Sobieski received as a result of the division ${ }^{27}$.

Stanisław Zygmunt Druszkiewicz, like Marek Matczyński, began his political career even before the election of King Jan III. However, the effect of his efforts was much smaller. He then became a land clerk. In 1660 he was appointed a carpenter of Parnawa ${ }^{28}$. During the reign of Jan III Sobieski, he became a senator after he received the Chełm castellany from the king in 1685. Kazimierz Piwarski established that after 1686, i.e. after an unsuccessful military mission in the camp near Jazłowiec during Jan III's Moldavian expedition, Druszkiewicz didn't play a major role ${ }^{29}$. It is very possible that it was then that he took up various duties in the Jan III's latifundium. This is indicated by a letter written by one of the managers - Adam Marcin Piotrowski. It shows that Druszkiewicz looked after the Pilaszkowice estate ${ }^{30}$. Druszkiewicz was, among others, the author of the economic instruction prepared for the writer on the income and expenditure of Pilaszkowice land estates ${ }^{31}$. However, it is unlikely that the Chełm castellan will become more involved in the economic obligations of the king. It is known for certain that he still remained an active soldier. In 1691, his troops captured Soroka in Moldavia ${ }^{32}$. When in 1692, on the order of Jan III Sobieski, 200 dragoons were formed in the Zamość ordination, the function of their commander was entrusted to Druszkiewicz ${ }^{33}$. It was a private branch in the services of the state and it can be assumed that - as the hetmans usually expected - the amount of the pay spent for this purpose will be compensated by the state treasury ${ }^{34}$.

Artillery expenses were included in the financial settlements of the latifundium. The cannoneer brought from Gdańsk to Żółkiew received 1092 zlotys in 168935. In 1687, 10,000 zlotys were spent on artillery in the Złoczów estates, which meant $50 \%$ of the income from these lands. However, not always such large amounts of money were spent on artillery. In 1688, expenses for a lieutenant, rifles and gunpowder made up only $13 \%$ of the income ${ }^{36}$. The issue of the participation of Jan III's private artillery in military campaigns, as well as the supply of ammunition to the Crown Army from the royal private resources, requires separate, more detailed scientific research.

An analysis of the relationship between Jan III Sobieski and the people he distinguished shows that there were many mutual benefits. Social promotion was more difficult if the candidate for the office did not come from a senatorial family ${ }^{34}$. It can be assumed that, especially in the case of Atanazy Walenty Miączyński, economic activity in the Sobieski family was conducive to career development. However, the function of the plenipotentiary was not a necessary condition for this. Not all the people distinguished by Jan III Sobieski achieved the same. More important offices were entrusted primarily to Marek Matczyński. Stanisław Zygmunt Druszkiewicz's career was considerably less brilliant. Druszkiewicz joined the group of senators thanks to Jan III, and Matczyński and Szczuka received ministerial offices only during the reign of Sobieski. Jan III certainly counted on the ability to manage a team of people acquired by his comradesin-arms in the course of his military service. However, their other advantage was also important - good orientation in political matters and exerting an appropriate influence on the nobility.

\section{Military expenditure}

Jan Sobieski's lands in the south-east of the country often experienced war damage. This concerned, among other things, the extensive, but not profitable for this reason, Złoczów estate ${ }^{35}$. The losses were, however, compensated by income from other parts of the latifundium. Jan Sobieski repeatedly granted loans to the state treasury. In 1667 , he paid the pay due to the Tatars who served the state from private money. He devoted 2,000 zloty for this purpose, and what is more, he also put in cash for the repair of the fortifications of Kamieniec Podolski - at least 300,000 35 . However, these are calculations estimated by Sobieski himself 
and it is difficult to accept this amount without reservations. He couldn't wait to get that money back ${ }^{36}$. It wasn't until the Parliament in 1673 that Sobieski was granted a refund of 63,165 zloty ${ }^{37}$. After his coronation, an exception was made. He was allowed to keep the starosties granted to him earlier. It was a compensation for the expenses incurred by the new king for the legations and wages for the army ${ }^{38}$. The highest, probably, loan granted by Sobieski to the state treasury was the sum to pay - for the entire quarter - for the Crown Army in 1689 and a quarter of infantry and dragoons in $1691^{39}$.

In reality, however, Sobieski had his own debts. Before the death of his brother Marek and mother Teofila, he took out loans. The money was used to pay for military expeditions. When in 1650 he borrowed 1000 zlotys from Katarzyna Kruszelnicka, this sum was secured on all his hereditary lands ${ }^{38}$. In 1658, Sobieski took out a loan against which he mortgaged his silver tableware ${ }^{39}$. He needed this money because he was planning a military trip to Prussia. This practice was not unique among magnates. When Sobieski was the hetman, he had to mortgage the jewels by taking out a loan of 10,000 zloty ${ }^{40}$. In 1666, Sobieski decided to mortgage the golden florins against a loan of a low value $\operatorname{coin}^{41}$. Sobieski's land goods were mostly burdened with debts. In 1668 he needed money for a war expedition. He had to borrow 80,000 zlotys, so almost all of his villages in the Żólkiew estate became the pledge ${ }^{42}$. Financial difficulties intensified during the hostilities. Money was "frozen" in earthly goods, so some of them had to be sold or mortgaged to get cash. Fears of the war meant that in 1671 Sobieski had difficulty finding a buyer who would agree to pay 200,000 thalers ${ }^{43}$. Jan Sobieski was also in debt when he was already king. At the time in question, the conditions for the loan were difficult, as the repayment of debts was in a worse coin than the loan ${ }^{44}$. An example of this can be the case of the return of the loan that the Gdańsk city magistrate paid to Jerzy Tyzenhauz in a gold coin. As Sobieski noted - this could only occur in a silver coin ${ }^{45}$. In the last decades of the 17th century and in the first half of the 18th century, it was common in Rus to borrow money by moneylenders against the pledge of land ${ }^{46}$. It was more advantageous to borrow from the nobility and clergy. The aforementioned compensation for expenses awarded to Sobieski by the Parliament was not sufficient to meet his financial needs. In 1673 he had to borrow money again, this time from Gabriel Silnicki. It was 15,798 zloty ${ }^{47}$. The loan was secured on all lands belonging to Jan Sobieski. In 1693, 135,055 zlotys were paid from the private treasury of the Sobieski family to strengthen the fortresses captured in Moldavia ${ }^{48}$. In 1696, he lent the state 800 zlotys to pay for the army. The money came from the income of the Czemierniki ${ }^{49}$. Jan III became interested in the fate of the royal properties of Šiauliai, located in the northeastern part of Samogitia. These goods were pledged to Paweł Jan Sapieha for a period of six years. The price of the pledge was a loan of 800,000 zloty, which was spent on payroll for the Lithuanian army. In 1678, these lands were bought from the Sapieha not by the state, but by Jan III with the consent of the Parliament ${ }^{50}$.

As Jan Głowacki has already noted, more attention should be paid than before to the issue of medical care organized for soldiers ${ }^{51}$. Unfortunately, expenses for the treatment of sick soldiers were not displayed in the books of expenses. One can only guess that the money spent on the needs of soldiers could also be used for such a purpose. King Jan III (1629-1696), who cared about the fate of the faithful knighthood, was always accompanied by a large group of doctors during his military expeditions. It was led by an adjunct physician, a Venetian, Dr. Alojzy Anselm, who was at the same time a trusted royal secretary. The court doctors also included: Polish nobleman Dr. Janusz Abraham Gehema, Dr. Ludwik Alembek from Lviv, later head of the Bonifraters' Hospital in Lviv, Dr. Wawrzyniec Braun (? -1690), a distinguished physician, distinguished by the king with land, and in 1673 nobility. These doctors treated not only the king himself, but also his court. Confidence in Doctor Emanuel Jona did not discourage the Sobieski family from constant search for good doctors, preferably foreigners. The latter ones were, in any case, necessary during foreign travels and war expeditions. In 1683, on the way to Vienna, Jan III Sobieski received a letter from his wife complaining of strange pain in her fingers. He promised to look for a suitable, famous doctor, apparently of foreign origin ${ }^{51}$. Doctor Peccorini was a physician found at that time $\mathrm{e}^{52}$. He was considered to be an expert in his field, so hoping for the doctor's effective medical service in the royal army, Sobieski paid him the salary out of his treasury. However, he was unhappy that the senior doctor - the Jesuit Hacki - refused to take advantage of the doctor's knowledge because Peccorini was not in the register owned by the Order ${ }^{53}$. Meanwhile, dysentery and other dangerous infectious diseases spread among soldiers weary of toils of Viennese campaign. The campaign was still ongoing, and the army was decreasing in number because it was difficult to forbid soldiers to return to the country because of poor health. Of course, this situation was not changed by Jan III's takeover of the all medicines of Grand Vizier Kara Mustafa. However, they were thoroughly 
viewed, and the commonly admired content was described by the king in a letter to his wife ${ }^{54}$. Particular attention was paid to fragments of embalmed human bodies - a respected medicine for many diseases.

During the war, soldiers fell ill and died as a result of wounds or infectious diseases. However, there have been cases of hypochondria in the army. One such case was described by the king himself. Writing a lot and in details about their ailments, Baroque people distinguished a real disease from what was then regarded as "shameful hypochondria" - which was their name for this phenomenon and probably often confusing it with depressive states. Jan III Sobieski briefly described its symptoms in a letter to his wife on the example of ailment of unknown by the name Polanowski:

"I sent out for him, arguing that it would be the best to let him, a sick person, stay here, in Gliwice. at the monastery of Reformed Fathers at that great time, close to the border, and after having been cured, he would already follow us closer; even to be sick in this country would be more decent, because everyone would say that the sick lies, where there is a war, and he would not be angry, and if he had to die it is as far from Silesia to heaven, as it is from Poland. I didn't get any response from him on it. He was seen in the church on the mass in Częstochowa by the poviat starost of Euck, he only spent the night there and after the service, he was going to go to Poland: he was complaining, he was crying because of his misfortune. I can see nothing more than only hypochondria, which is scarier than anything else, when it deprives of the fame and reputation)"

Jan III Sobieski took care of increasing the family's wealth, he created a control system consisting of plenipotentiaries, and there is relatively little information about his debts. Therefore, it seems that his economy can be assessed positively, although due to his numerous duties, he was not always able to personally control people's work and bills. He was as much a lender as a borrower, and in the light of the preserved bills and mentions in historical sources, military expenditure constituted an important, though not the most important, part of his expenditure ${ }^{56}$.

The economic basis of the magnate's power is an issue that requires more extensive research. This issue was primarily of interest to historians dealing with latifundia in the 18th century. This was mainly due to the source material. Latifundial documentation was kept much more regularly in the 18th century than before and is well-organized. The economic activity of the magnate was related not only to the internal organization of landed estates. It cannot be separated from the military, because the goal of the magnate's life was politics and, very often, also war. Despite its autonomy, the latifundium wasn't isolated. Despite the existence of the decentralization process of the state, the magnate families remained in contact with the weakening center of the state and influenced changes in its social structure. The actual strength of the magnate family was determined not only by the area of land goods, but above all by their profitability, which depended on several factors: geographic location and natural conditions, the current situation on the economic market, and the management method adopted by the magnate. In the 17th century, crisis phenomena, visible in demography, agricultural and crafts production, money and trade, intensified. In these realities, attempts by Jan III Sobieski to reconstruct the lands destroyed by the war and to introduce military rigor in the management center did not bring the expected results. Sobieski, however, introduced "new people" to the group of senators, who implemented his policy at the sejmiks and the Parliament, and participated in military expeditions and managed his property.

\section{Bibliography}

\section{Material archival}

Archiwum Główne Akt Dawnych: Archiwum Publiczne Potockich, 7; Archiwum Radziwiłłów V; Archiwum Zamoyskich, 1326; Zbiór Czołowskiego 376, 391, 392, 422, 499, 1056.

Archiwum Państwowe w Gdańsku, 300, 12/392.

Biblioteka Akademii Nauk Ukrainy im. W. Stefanyka we Lwowie, fond Ossolinnskich, 66.

Centralnyj Dierżawnyj Archiw Ukraini Lviv, 132-1-750.

Nacjanalny Gistaryczny Archiv Belarusi Minsk, 694-2-274, 282, 286, 649-651, 1274, 1275, 2024-2029, 2451, 2461 , 6549, 9527. 


\section{Source editions}

Maria Kazimiera i Jan Sobiescy, Listy okresu odsieczy wiedeńskiej, Wydawnictwo Czytelnik, Warszawa, 1983 (in Polish).

Nieznane listy Jan Sobieski, ed. G. Klimecka, Biblioteka Narodowa, Warszawa, 1987 (in Polish).

Sobieski J., Listy do Marysieńki, vol. 1-2, ed. L. Kukulski, Czytelnik, Warszawa, 1973 (in Polish).

\section{Studies}

Anusik Z., Latyfundia książąt Zbaraskich w XVI i XVII wieku, „Przegląd Nauk Historycznych”, vol. 8, 1, Wydawnictwo Uniwersytetu Łódzkiego, Łódź, 2009, 17-77 (in Polish).

Bogucka M., Kryzys monetarny XVII wieku. Konsekwencje społeczne i psychologiczne w Polsce, „Roczniki Dziejów Społecznych i Gospodarczych”, 1976 (in Polish).

Chłapowski K., Starostowie niegrodowi w Koronie 1565-1795. Materiały źródłowe, Bellerive-sur-Allier, Warszawa, 2017 (in Polish).

Ciara S., Senatorowie i dygnitarze koronni w drugiej połowie XVII w., Zakład Narodowy imienia Ossolińskich, Wrocław, 1990 (in Polish).

Czapliński W., Długosz J., Życie codzienne magnaterii polskiej w XVII wieku, Państwowy Instytut Wydawniczy, Warszawa, 1982 (in Polish).

Długosz J., Latyfundia Lubomirskich w XVII wieku (powstanie-rozwój-podziały), Wydawnictwo Uniwersytetu Opolskiego, Opole, 1997 (in Polish).

Gierowski A., Między absolutyzmem a złotą wolnością. Z dziejów wewnętrznych Rzeczypospolitej w latach 1712-1715, Zakł. Narod. im. Ossolińskich, Wrocław, 1953 (in Polish).

Głombiowski K., Ksenofont. Żołnierz i pisarz, Zakład Narodowy im. Ossolińskich, Wrocław, 1993 (in Polish). Historia chłopów polskich, vol. 1, red. S. Inglot, Wrocław 1992 (in Polish).

Historia kultury materialnej Polski w zarysie, t. 4: Od połowy XVII do końca XVIII wieku, red. Z. Kamieńska i B. Baranowski, Zakład Narodowy im. Ossolińskich, Wrocław, 1978 (in Polish).

Hundert Z., Strażnicy koronny i wojskowy w dobie Jana Sobieskiego (1667-1696). Kilka uwag o osobach odpowiedzialnych za organizowanie przemarszów armii koronnej, „Acta Universitatis Lodziensis”, Folia Historica 99, Wydawnictwo Uniwersytetu Łódzkiego, Łódź, 2017 (in Polish), 149-170.

Kaniewski J., Sejmiki koronne wobec problemów wewnętrznych Rzeczypospolitej za panowania Michała Korybuta Wiśniowieckiego (1669-1673), Uniwersytet Śląski, Katowice, 2014.

Korzon T., Dola i niedola Jana Sobieskiego 1629-1674, Akademia Umiejętności, Kraków, 1898 (in Polish).

Kotarski H., Marek Matczyński, [in] Polski Słownik Biograficzny, t. 20, Zakład Narodowy imienia Ossolińskich,Wrocław, 1975, 175-176 (in Polish).

Kowalski M., Ordynacja Zamojska jako państwo magnackie Rzeczypospolitej Szlacheckiej, „Przegląd Geograficzny”, vol. 81, 2, Instytut Geografii i Przestrzennego Zagospodarowania im. Stanisława Leszczyckiego PAN, Warszawa, 2009, 173-203 (in Polish).

Kurtyka J., Latyfundium Tęczyńskie. Dobra i właściciele (XIV - XVII wiek), Księgarnia Akademicka, Kraków, 1999 (in Polish)

Nagielski M., „Partia dworska” w schyłkowym okresie panowania Jana Kazimierza Wazy (1664-1668), [in] idem, Druga wojna domowa w Polsce. Z dziejów polityczno-wojskowych u schyłku rządów Jana Kazimierza Wazy, Wydawnictwo Neriton, Warszawa, 2011 (in Polish).

Piwarski S., Druszkiewicz Stanisław, [in] Polski Słownik Biograficzny, vol. 5, Polska Akademia Umiejętności, Kraków, 1939-1946 (in Polish).

Schnayder J., Wstęp, [w:] Ksenofont, Wybór pism, oprac. J. Schnayder, Zakład Narodowy im. Ossolińskich, Wrocław, 1966 (in Polish).

Ujma M., Latyfundium Jana Sobieskiego1652-1696, Wydawnictwo Uniwersytetu Opolskiego, Opole 2005 (in Polish). 
Urzędnicy centralni i nadworni Polski XIV-XVIII wieku. Spisy, red. A. Gąsiorowski, Biblioteka Kórnicka, Kórnik, 1992, 185 (in Polish).

Wagner M., Korpus oficerski wojska polskiego w drugiej połowie XVII wieku, Wydawnictwo Napoleon V, Oświęcim, 2015 (in Polish)

Wielebska Z., Powstanie majątku Stanisława Koniecpolskiego (1591-1646), hetmana wielkiego koronnego, „Studia Historyczne”, vol. 24, 4, Polska Akademia Nauk, Kraków, 1981, $547-556$ (in Polish).

Wimmer J., Miączyński Atanazy Walenty, [in] Polski Stownik Biograficzny, vol. 22/3, Zakład Narodowy Imienia Ossolińskich i Wydawnictwo Polskiej Akademii Nauk, Wrocław - Warszawa - Kraków - Gdańsk, 1975, 553-555 (in Polish).

Wimmer J., Wojsko polskie w drugiej połowie XVII wieku, Wydawnictwo Napoleon V, Oświęcim, 2019 (in Polish).

Wójcik Z., Jan Sobieski, Państwowy Instytut Wydawniczy, Warszawa, 1983 (in Polish). 